\title{
Chemothorax: a rare cause of a transudative pleural effusion
}

\author{
Devin Kelly, David Geottman, Bipin Sarodia
}

Department of Internal Medicine, Wright State School of Medicine, Dayton, Ohio, USA

\section{Correspondence to} Dr Devin Kelly, devinkel@gmail.com

Accepted 21 November 2015

\section{SUMMARY}

We discovered a rare cause of pleural effusion, chemothorax. In this case, a patient with invasive ductal breast carcinoma was admitted for a large and symptomatic pleural effusion. The radiology report obtained prior to admission did not describe the location of the Infuse-a-Port catheter. After a bedside thoracentesis demonstrated results consistent with chemotherapy infusate in the pleural space, further review of the medical imaging demonstrated that the catheter was in the pleural space.

\section{BACKGROUND}

This case highlights the importance of re-evaluating a clinical situation when presented with results that do not match your clinical suspicion. There are times in the practice of medicine when you are presented with results or findings that are unexpected. These cases warrant further investigation or revisiting details in order to accurately diagnose and treat patients.

\section{CASE PRESENTATION}

A 50-year-old Caucasian woman diagnosed with invasive ductal breast carcinoma status post left modified radical mastectomy presented to the emergency room, for back pain and shortness of breath that started while receiving chemotherapy earlier that day. The patient received her chemotherapy infusion via a tunnelled right internal jugular port that had been placed a month earlier under ultrasound and fluoroscopic guidance. Placement of the line had been immediately confirmed after the procedure, with a single-view anteroposterior portable chest film, which appeared to show the catheter tip in the superior vena cava. On presentation, she was on cycle $2 / 4$ of docetaxol $140 \mathrm{mg}$ and cyclophosphamide $1150 \mathrm{mg}$, which she received along with a $1 \mathrm{~L}$ bolus of normal saline for prehydration.

The patient had undergone a similar experience 21 days earlier while undergoing her first chemotherapy infusion; her symptoms of shortness of breath and pain had lasted 2 weeks after that infusion. She was afebrile with blood pressure 135/ $81 \mathrm{~mm} \mathrm{Hg}$, pulse rate $92 \mathrm{bpm}$ and respiration rate 20 breaths/min. She had absent breath sounds and dullness to percussion over the right hemithorax.

To cite: Kelly $D$

Geottman D, Sarodia B. BMJ Case Rep Published online: [please include Day Month Year] doi:10.1136/bcr-2015212691

\section{INVESTIGATIONS}

A portable radiograph in the emergency room demonstrated a large right pleural effusion with near complete whiteout of the right hemithorax (figure 1). Computerised axial tomography of the chest following administration of $100 \mathrm{cc}$ of intravenous iohexal demonstrated a large right pleural effusion with near complete atelectasis of the right lung without evidence of a pulmonary embolism. The patient was admitted for a large symptomatic right pleural effusion. Once admitted, she underwent a bedside thoracentesis. Clear fluid measuring 1.2 L was removed, and the patient's dyspnoea and pain improved. The fluid studies demonstrated a transudative effusion with a pleural lactate dehydrogenase $22 \mathrm{U} / \mathrm{L}$, protein $0.2 \mathrm{~g} / \mathrm{dL}$, white cell count $16 / \mathrm{mm}^{3}$ and red blood cell count $173 / \mathrm{mm}^{3}$. Fluid sodium was $144 \mathrm{mEq} / \mathrm{L}$ and fluid chloride was $125 \mathrm{mEq} / \mathrm{L}$. A re-evaluation of the imaging showed that the catheter was in an extravascular location, terminating in the right pleural space (figures 2 and 3).

\section{DIFFERENTIAL DIAGNOSIS}

The patient presented with her second occurrence of acute dyspnoea over the past month, and both of these occurrences started during chemotherapy infusion of docetaxel and cyclophosphamide. The gross appearance of the fluid returned on the thoracentesis was atypical, as it was as clear as water, and not bloody or the typical straw colour of a transudative fluid. We were expecting a malignant effusion that was grossly bloody, hazy or opaque. The water-like appearance of the fluid caused us to re-assess the imaging. We discovered that the previously placed 'right internal jugular' Infuse-a-Port was not in the vein but, rather, its tip was located

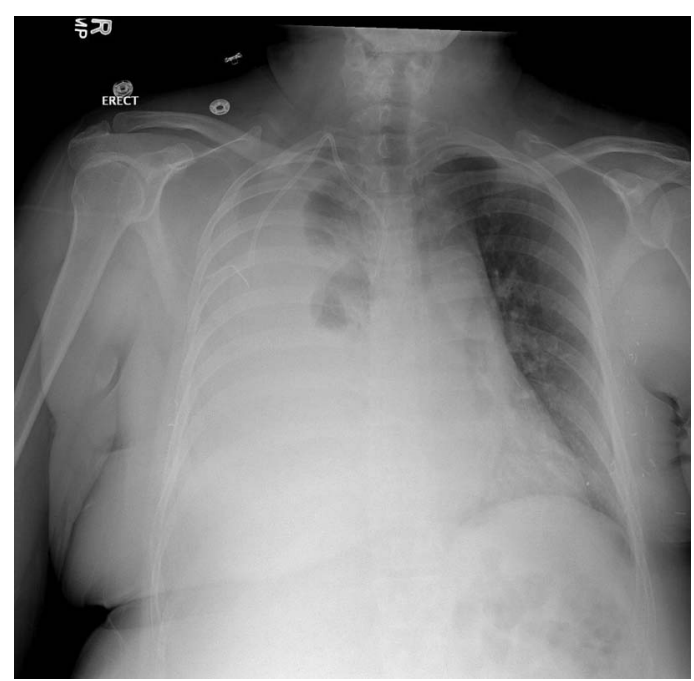

Figure 1 A large right pleural effusion. 


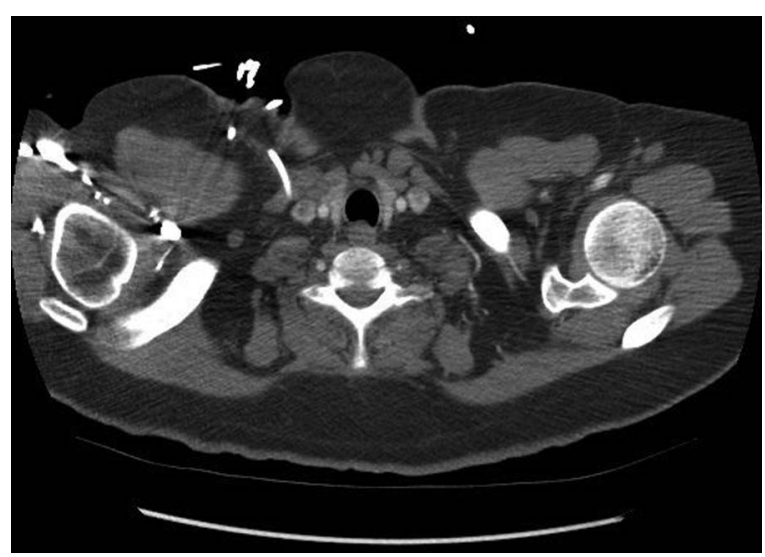

Figure 2 The port catheter in an extravascular location.

within the right pleural space. As a result of this malposition, the patient's infusate was being delivered into her pleural space.

\section{TREATMENT}

After discovery of the port catheter location, the patient underwent placement of a right pleural pig-tail catheter with further removal of the remaining pleural fluid. The right jugular port was then removed and replaced.

\section{OUTCOME AND FOLLOW-UP}

The patient developed a recurrent right pleural effusion with exudative characteristics from pleuritis caused by the previously infused chemotherapy agents. She gradually improved with repeat thoracentesis, which was negative for malignancy on cytology testing. A small effusion remained on her most recent CT scan.

\section{DISCUSSION}

Published reports have described cases of central venous catheters being placed in the pleural space, with infusion of various medications causing pseudochylothorax, hydrothorax or tension

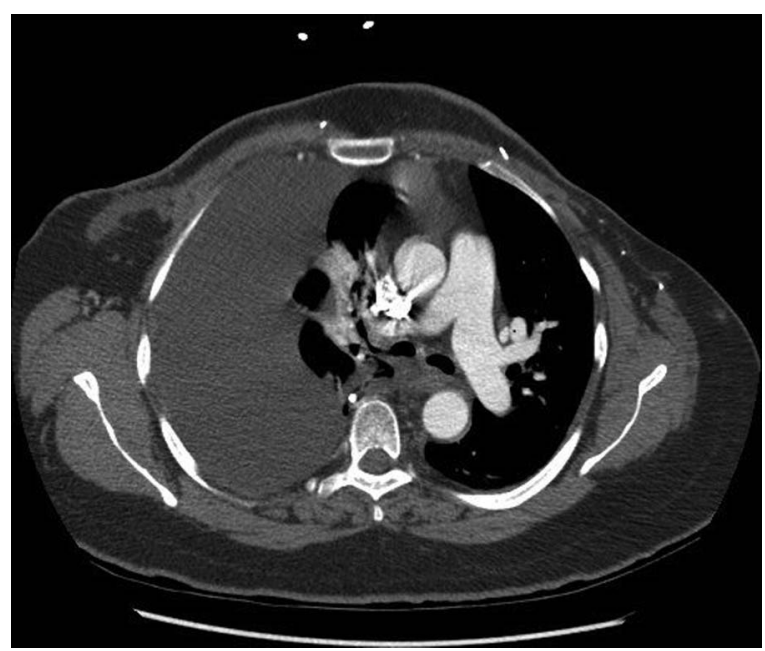

Figure 3 The port catheter tip in the pleural space. pneumothorax. ${ }^{1-3}$ There are numerous complications from the placement of an Infuse-a-Port, such as pneumothorax, bleeding, infection, thrombosis, arrhythmia, vascular injury, migration and venous air embolism. ${ }^{4-10}$ We found a previous case report of a chemotherapeutic agent infused in the pleural space with an Infuse-a-Port. Accidental injection into the chest near the side of the port and not into the port caused the infusion into the pleural space; the port functioned properly. ${ }^{11}$ While malposition of an Infuse-a-Port is a complication, it is usually discovered early. ${ }^{6}$ There have been occasions of central venous catheters that were functioning properly at placement, but then delayed perforation occurred with migration of the catheter tip into the pleural space. ${ }^{12}$ Our patient's port was in an extravascular location throughout its course, making delayed perforation and migration unlikely. We did not find reports of complications due to medication from an Infuse-a-Port inserted into the pleural space. $^{5-11}$

\section{Learning points}

- Re-evaluate a clinical situation when results do not match your clinical suspicion.

- Review all images and results yourself.

- Investigate unexpected findings further.

Competing interests None declared.

Patient consent Obtained.

Provenance and peer review Not commissioned; externally peer reviewed.

\section{REFERENCES}

1 Leang LT. Intrapleural central venous catheter malposition. Med J Malaysia 1989:44:147-50.

2 Puttagunta HK, Seneviratne C, Kupfer Y, et al. Pseudochylothorax and diaphragmatic weakness secondary to a misplaced central venous catheter. $B M J$ Case Rep 2013;2013:pii: bcr2013008765.

3 Maround R, Chalhoub M, Harris K. Right internal jugular venous cannulation complicated by tension hydrothorax. Heart Lung 2013;42:372-4.

4 Young MP. Complications of central venous catheters and their prevention. In: Post TW, ed. UpToDate. Waltham, MA: UpToDate, 2015. http://www.uptodate.com/ contents/complications-of-central-venous-catheters-and-their-prevention (accessed 13 Jan2015).

5 Fallon SC, Larimer EL, Gwilliam NR, et al. Increased complication rates associated with Port-a-Cath placement in pediatric patients: location matters. J Pediatr Surg 2013;48:1263-8.

6 Granic M, Zdravkovic D, Krstajic S, et al. Totally implantable central venous catheters of the Port-a-Cath type: complications due to its use in the treatment of cancer patients. J BUON 2014;19:842-6.

7 Ahn SJ, Kim HC, Chung JW, et al. Ultrasound and fluoroscopy-guided placement of central venous port via internal jugular vein: retrospective analysis of 1254 port implantations at a single center. Korean J Radiol 2012;13:314-23.

8 Tsai YF, Ku YH, Chen SW, et al. Right-and left-subclavian vein Port-a-Cath systems: comparison of complications. Eur Surg Res 2012;49:66-72.

9 D'Souza PC, Kumar S, Kakaria A, et al. Use of Port-a-Cath in cancer patients: a single-center experience. J Infect Dev Ctrics 2014;8:1476-82.

10 Botha R, van Schoor AN, Boon JM, et al. Anatomical considerations of the anterior approach for central venous catheter placement. Clin Anat 2006;19:101-5.

11 Pronchik DJ, Sexton J. Emergency department presentation of an unusual pleural effusion. Am J Emerg Med 1998;16:163-5.

12 Iberti TJ, Katz LB, Reiner MA, et al. Hydrothorax as a late complication of central venous indwelling catheters. Surgery 1983;94:842-6. 
Copyright 2015 BMJ Publishing Group. All rights reserved. For permission to reuse any of this content visit http://group.bmj.com/group/rights-licensing/permissions.

BMJ Case Report Fellows may re-use this article for personal use and teaching without any further permission.

Become a Fellow of BMJ Case Reports today and you can:

- Submit as many cases as you like

- Enjoy fast sympathetic peer review and rapid publication of accepted articles

- Access all the published articles

- Re-use any of the published material for personal use and teaching without further permission

For information on Institutional Fellowships contact consortiasales@bmjgroup.com

Visit casereports.bmj.com for more articles like this and to become a Fellow 